\title{
Foodborne Botulism in Ukraine from 1955 to 2018
}

\author{
Nataliia Semenko, ${ }^{1}$ Hennadii Mokhort, ${ }^{1}$ Olga Sokolovska, ${ }^{1}$ \\ Iryna Kolesnikova, ${ }^{1}$ Ihor Kuzin, ${ }^{2}$ and Karen Saylors ${ }^{3}$
}

\begin{abstract}
We aim to identify possible biological, social, and economic factors that could influence the prevalence of foodborne botulism (FB). The objective of this article is to assess epidemiological peculiarities of FB in Ukraine from 1955 to 2018 using national epidemiological surveillance data. This article presents an epidemiological descriptive population-based study of the epidemiology of FB using correlation analysis. From 1955 to 2018, 8614 cases of botulism were recorded in Ukraine causing 659 deaths. The distribution of types of botulism toxins is represented by type A $(7.97 \%)$, B $(59.64 \%)$, suspected as C $(0.56 \%)$, E (25.47\%), others $(5.33 \%)$, and unidentified (1.04\%). From 1990 to 2015, the rate correlation between Human Development Index (HDI) and incidence of botulism was $-0.75 \pm 0.20$. Homemade canned meat and fish continue to be the leading causes of botulism in Ukraine. Cases related to commercial food were rare or absent, but in recent years (2017-2018), their percentage has increased to $32.56 \%$. The HDI and botulism have an inverse mathematical correlation and predictable logical relationship: with an HDI increase, the incidence of FB decreased. In general, food botulism in Ukraine is related to traditional socioeconomic factors related to cultural food habits. In the face of declining living standards and uncertainty that food products will be physically or economically available, homemade preservation increases. Home food preservation is a major cause of botulism in Ukraine. The elimination of FB is possible in Ukraine only with the complete cessation of home canning and state control over the manufacture and sale of commercial canned products.
\end{abstract}

Keywords: foodborne botulism, retrospective study, Ukraine

\section{Introduction}

$\mathbf{F}$ OODBORNE BOTULISM (FB), also known as bacterial food poisoning, is the most common clinical form of human botulism. Clostridium botulinum causes a relatively rare, but very serious disease with a high fatality rate. The severe disease course with prolonged hospital length-of-stay, as well as high fatality rates, classifies FB as an important public health problem (Maksymchuk, 2006). Moreover, botulinum neurotoxin (BoNT) has a significant potential as a biological weapon (Arnon et al., 2001). Botulinum toxin belongs to category A of Bioterrorism Agents (CDC, 2018). Great diversity exists within BoNT, which has seven well-established serotypes (BoNT/A-G), with evidence of a hybrid between $\mathrm{A}$ and $\mathrm{F}$ that resulted in BoNT/H (Barash and Arnon, 2014), as well as a newly reported serotype, BoNT/X (Zhang et al., 2017).
Currently, seven types of BoNT are represented by more than 40 subtypes (Peck et al., 2017). FB in humans is primarily caused by types A, B, E, and to a lower extent F, and only 15 cases or suspected cases of botulism type $C$ have been reported in humans to date (Rasetti-Escargueil et al., 2019). Fish products are often toxin transmission vectors of type $\mathrm{E}$ (Zane Horowitz, 2010). Type A and B toxins are more commonly associated with plant foods (CDC, 1998). The incidence of FB is directly related to the particularities of canned food product preparation methods and food habits of the population (Tarkhashvili et al., 2015).

The epidemiology and incidence of FB vary geographically (Chatham-Stephens et al., 2017; Fleck-Derderian et al., 2017). For example, this disease is very rare in the United Kingdom, where 62 cases were recorded between 1922 and 2005 (McLauchlin et al., 2006). In Italy, which living standards and socioeconomic development can be compared with the

\footnotetext{
${ }^{1}$ Department of Epidemiology, Bogomolets National Medical University, Kyiv, Ukraine

${ }^{2}$ SI Public Health Center of the MoH of Ukraine, Kyiv, Ukraine.

${ }^{3}$ Labyrinth Global Health, Saint Petersburg, Florida, USA.
}

(c) Nataliia Semenko et al. 2020; Published by Mary Ann Liebert, Inc. This Open Access article is distributed under the terms of the Creative Commons Attribution Noncommercial License [CC-BY-NC] (http://creativecommons.org/licenses/by-nc/4.0/) which permits any noncommercial use, distribution, and reproduction in any medium, provided the original author(s) and the source are cited. 


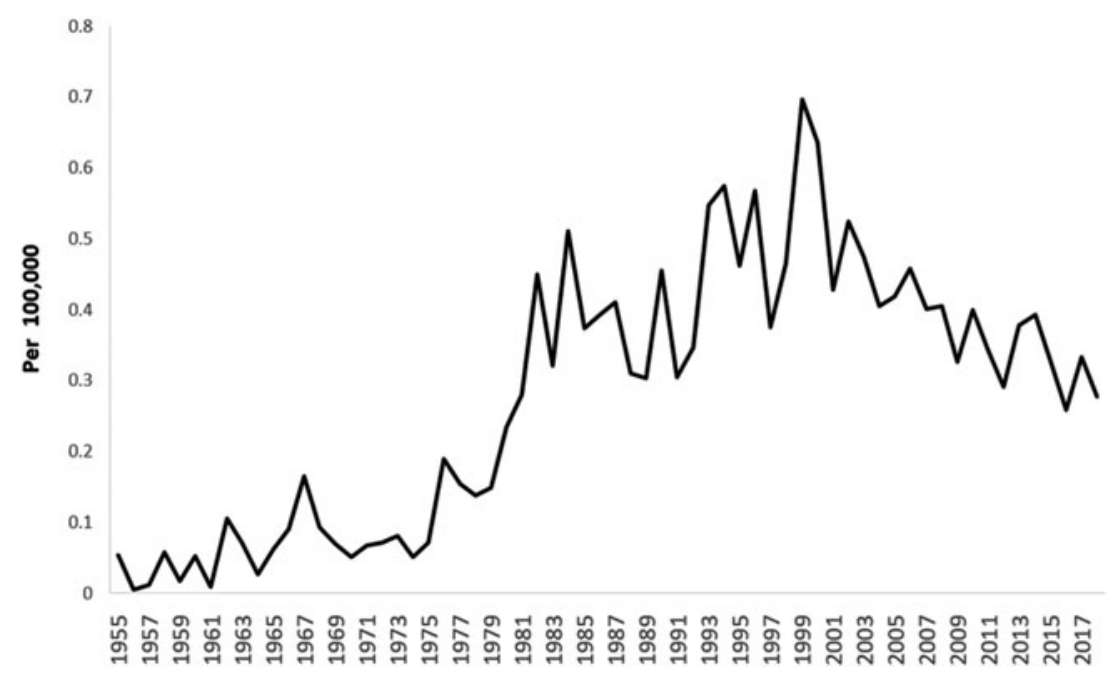

FIG. 1. Cumulative incidence of foodborne botulism in Ukraine (1955-2018).

United Kingdom, 466 confirmed cases of botulism were recorded between 1986 and 2015. Incidence rates (IRs) of botulism in Europe are 0.03 cases per 100,000 population (Anniballi et al., 2017). The highest botulism incidence in Europe was registered in Georgia where the average annual incidence of FB increased from 0.30 per 100,000 population in 1980-1990 to 0.90 per 100,000 population in 1999-2002 (Varma et al., 2004). Other European countries showed a decrease of botulism.

In 2001-2013, the IR of botulism in Poland decreased from 0.17 to 0.06 per 100,000 population (Czerwiński et al., 2015). In Romania, there was also a decrease in the incidence of botulism in the postcommunist period, but in 2007, Romania reported the highest incidence of botulism in the European Union-0.18 per 100,000 population (Neghina and Neghina, 2011). The cost of treatment and resuscitation of each case of this poisoning are tens of thousands of U.S. dollars (Mann, 1983). Taking this into consideration, FB, despite its low prevalence, has a high social and economic burden. In most countries, every case of this disease is subject to epidemiological investigation at the state level.
We have analyzed the data from the epidemiological surveillance of botulism in Ukraine from 1955 to 2018 to establish trends in IRs and/or cumulative incidence (CI) rates (CIR), mortality rate (MRs), event rates (ERs), and case fatality rates (CFR). We aim to identify possible biological, social, and economic factors that could influence the prevalence of FB. The objective of this article is to present the epidemiological assessment of FB in Ukraine from 1955 to 2018 using national epidemiological surveillance data. We carried out an analysis of IR, CIR, MR, ER, and CFR of FB over a 63-year period, focusing on the years of Ukraine's independence ( 28 years) to inform the country's public health service.

\section{Materials and Methods}

This work presents an epidemiological analysis and a descriptive population-based study of discrete time periods from 1955 to 2018 in Ukraine, describing the structure of the CIR, $\mathrm{MR}$, and CFR indicators for FB. Data on the annual total number of botulism events, cases, and deaths from FB for the period of 1955-2018 were provided by the Public Health

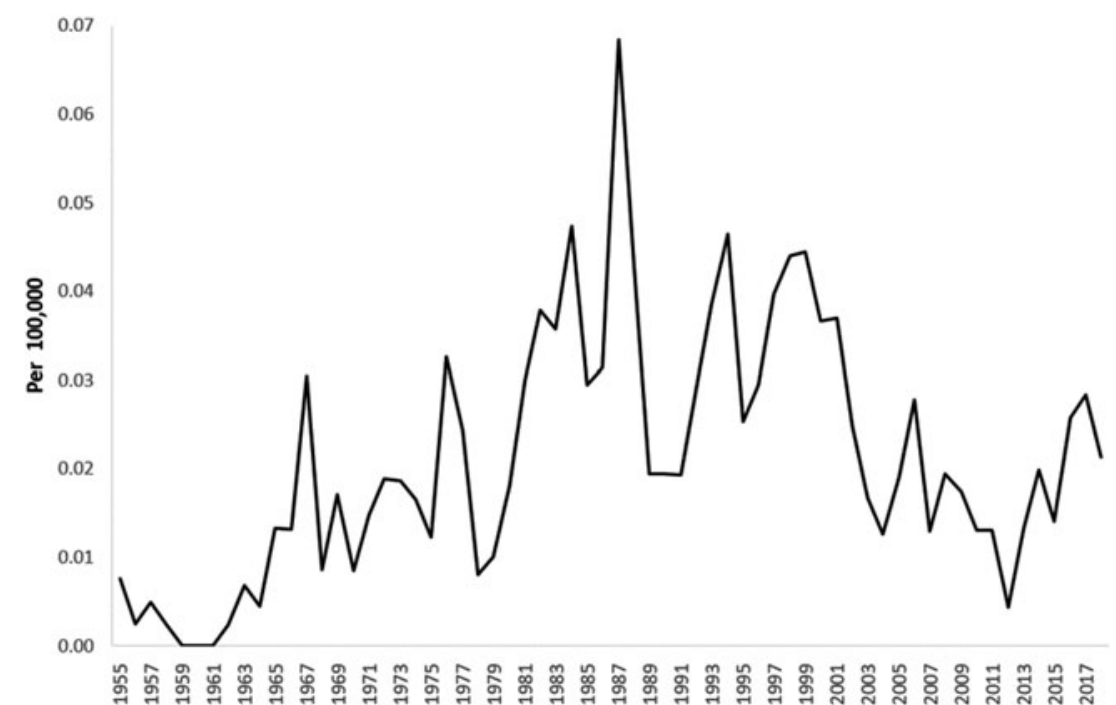

FIG. 2. Mortality rate of botulism in Ukraine (1955-2018). 


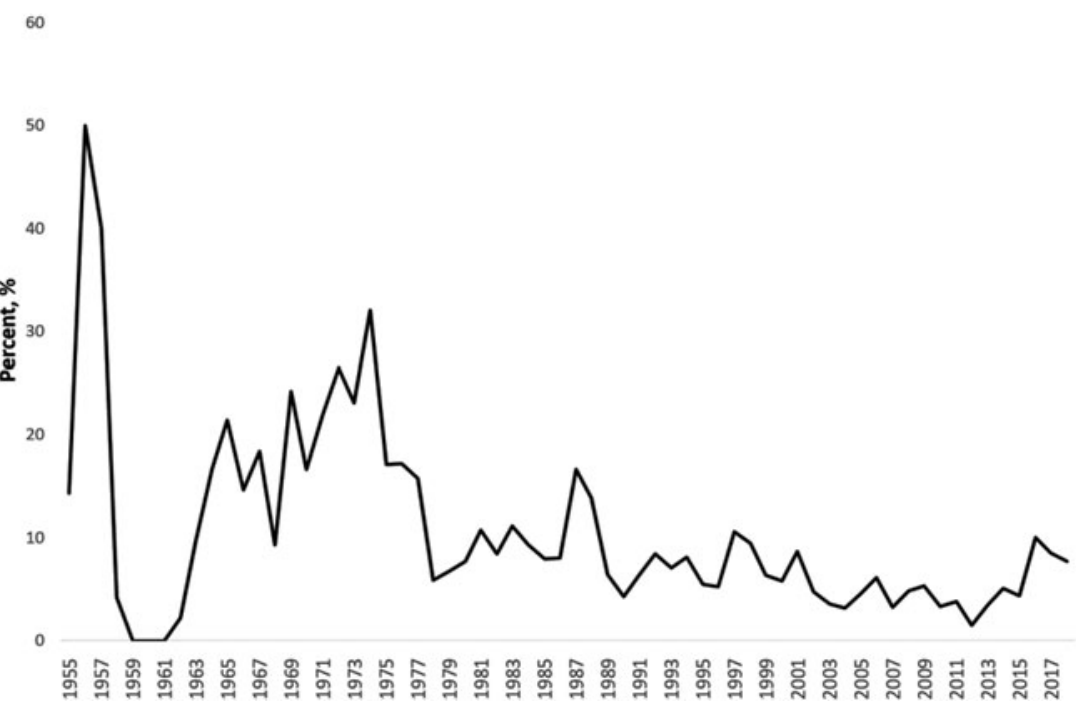

FIG. 3. Case fatality rate of botulism in Ukraine (1955-2018).

Center of the Ministry of Health of Ukraine. A botulism event is a case (or cases) of botulism associated with the consumption of a contaminated food product. ER of botulism is the number of cases of botulism per 1 event of botulism. All data on FB cases and botulism events for 1955-2018 were presented in a Microsoft Office Excel table distributing FB cases by years and administrative territory (region) of Ukraine. The authors obtained information about the total number of cases and deaths for the period of 1986-1990 in Ukraine.

The etiological structure of FB cases is presented only for 1955-1985, 1991-2002, and 2017-2018, as is the distribution of patients and deaths from FB according to transmission factors or contaminated products that they ate. The data on the Human Development Index (HDI) for 1990-2015 were taken from the European Regional WHO Office database. Data on the actual per capita income in Ukrainian hryvnias for the period of 2002-2017 were obtained from the State Statistics Service of Ukraine website.

We divided the entire study period (1955-2018) into two periods: 1955-1990 (years of Ukraine belonging to the Soviet Union) and 1991-2018 (years of Ukraine's independency). We established the time series of botulism and its trend lines, and compared the general and average weighted IRs, and MR and fatality rates of botulism during these two periods. Depending on the available data, we further divided the period of 19912018 into two unequal periods: 1991-2001 (2002 or 2003) the first decade of Ukraine's independence or the period of the deep social and economic crisis, and the period of 2017-2018 that characterizes the current state of Ukraine's development.

Our hypothesis predicts that changes in morbidity and MRs from FB in Ukraine for each time period (1955-1990, 1991-2002, and 2017-2018) depend on the level of social and economic development during each period and the consequent impacts on eating habits of the population in Ukraine. Office Excel 2003 was used only for calculating epidemiological indicators and for constructing time series figures. This study does not require IRB approval.

\section{Results}

During 1955-2018, 8614 cases of botulism were recorded in Ukraine. The dashed line for approximating the time series of annual botulism incidence has a bell-shaped curve with a peak in 1999, when 345 cases were recorded, or 0.70 per 100,000 population (Fig. 1). The number of recorded botulism cases was 5158 during the period of increased incidence (1955-1999), while during the period of incidence downturn (2000-2018), 3456 cases were recorded. Importantly, after Ukraine established its independence, a greater number of botulism cases (5665) were registered over the past 28 years (1991-2018); the CI for 28 years amounted to 11.92 cases per 100,000 population. A smaller number of botulism cases (2949) occurred during 35 years (1955-1990) when Ukraine was part of the Soviet Union.

During the entire period of botulism observation, 19552018, in Ukraine, 659 people died from this disease. The dashed line for approximating the time series of annual botulism MR has a bell-shaped curve with a peak in 1987 (Fig. 2). Even though the approximation lines of the botulism annual IRs and MRs coincide, the amplitude of the mortality fluctuations is much higher than the amplitude of the incidence fluctuations (from 0 to 35 deaths annually during 1955-2018). Almost the same number of botulism deaths (324 vs. 335) was recorded in the last years of Ukraine being part of the Soviet Union (1955-1990) as in the years of its

Table 1. Distribution of Cases and Deaths of Botulism in Ukraine for the Periods 1955-1985 and 1991-2018

\begin{tabular}{|c|c|c|c|c|c|c|}
\hline & \multicolumn{2}{|c|}{ No. of cases } & \multicolumn{2}{|c|}{ Case fatality } & \multicolumn{2}{|c|}{$C F R, \%$} \\
\hline & $1991-2018$ & $1955-1985$ & 1991-2018 & $1955-1985$ & 1991-2018 & 1955-1985 \\
\hline Ukraine, total & 5665 & 1989 & 335 & 231 & 5.91 & 11.61 \\
\hline
\end{tabular}

CFR, case fatality rate. 


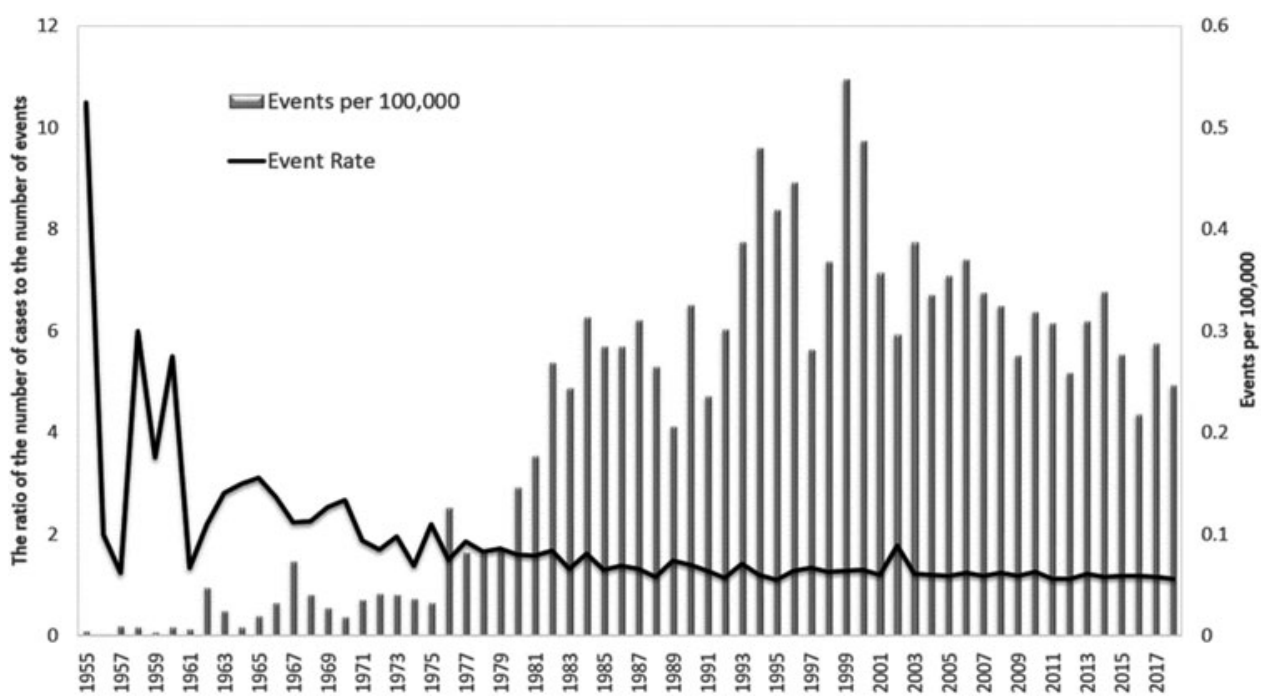

FIG. 4. Number of events per 100,000 and event rate of botulism in Ukraine (1955-2018).

independence (1991-2018). Botulism cumulative MR for the last 28 years in Ukraine were 0.71 per 100,000 population.

Botulism total annual CFR ranged from $0 \%$ to $50 \%$, and the CFR time series had a rather pronounced downward trend during the entire period of disease observation (1955-2018) in Ukraine (Fig. 3). Within the CFR trend line, five pronounced peak values of this indicator were observed: $1957-50.00 \%$, $1974-32.00 \%, 1987-16.67 \%, 1997-10.58 \%$, and $2016-$ $10.00 \%$. Botulism CFR ranged from $1.50 \%$ to $10.58 \%$ during the period of Ukraine's independence. The highest CFR values were recorded during the Soviet period and in the early years of Ukraine's independence. We hypothesize this is because the economic decline was greatest in these years and contributed to an increase in consumption of home canned foods.

Table 1 shows that the weighted average CFR for 19912018 compared with 1955-1985 decreased in Ukraine by 1.96 times (from $11.61 \%$ to $5.91 \%$ ). The time series of events per 100,000 population is approximately the same as the time series of botulism incidence. A total of 6447 botulism events were recorded over 64 years of observation. The number of botulism events during the Soviet period (36 years) amounted to 1.87 events. There were 4576 botulism events during the period of Ukraine's independence (28 years). The largest ER in Ukraine was during 1955-1970 (Fig. 4) and it ranged from 1.33 to 10.50 cases per 1 botulism event (the average value is 3.35 cases of botulism per 1 event) during that period.

The ER has been less than 2 cases per 1 botulism event, and the average value of this indicator was 1.38 cases of botulism per 1 botulism event since 1971. The average botulism ER during the Soviet period was 2.37 cases per 1 botulism event. After Ukraine's independence, the ER decreased by 1.92 times ( 1.23 cases per 1 botulism event).

We calculated the correlation coefficient between the HDI and botulism CIR in Ukraine for the period of 1990-2015 (Fig. 5), which was $-0.75 \pm 0.20(t=3.72)$, and determined the correlation coefficient between the average per capita

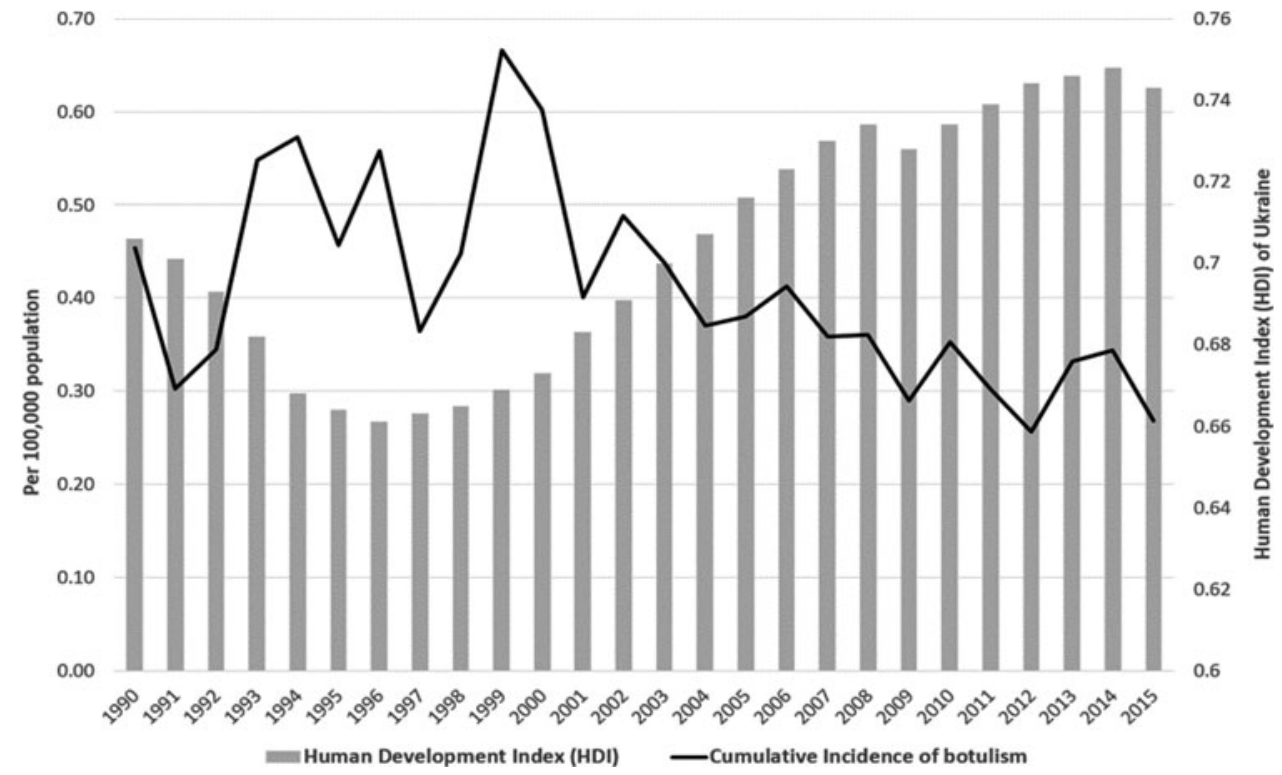

FIG. 5. Cumulative incidence of foodborne botulism and Human Development Index in Ukraine (1990-2015). 
Table 2. Types of Botulinum Pathogens IN UKRAINE (1955-2018)

\begin{tabular}{|c|c|c|c|c|}
\hline Years & $1955-1985$ & 1991-2002 & 2017-2018 & Total \\
\hline $\begin{array}{l}\text { Total cases } \\
\text { of botulism }\end{array}$ & 1989 & 2982 & 258 & 5229 \\
\hline \multicolumn{5}{|c|}{ Including laboratory confirmation of the diagnosis } \\
\hline$N$ & 996 & 1201 & 112 & 2309 \\
\hline$\%$ & 50.08 & 40.27 & 43.41 & 44.16 \\
\hline \multicolumn{5}{|l|}{ Type A } \\
\hline$N$ & 115 & 64 & 5 & 184 \\
\hline$\%$ & 11.55 & 5.33 & 4.46 & 7.97 \\
\hline \multicolumn{5}{|l|}{ Type B } \\
\hline$N$ & 623 & 718 & 36 & 1377 \\
\hline$\%$ & 62.55 & 59.78 & 32.14 & 59.64 \\
\hline \multicolumn{5}{|l|}{ Type $C^{a}$} \\
\hline$N$ & 11 & 0 & 2 & 13 \\
\hline$\%$ & 1.10 & 0.00 & 1.79 & 0.56 \\
\hline \multicolumn{5}{|l|}{ Type E } \\
\hline$N$ & 247 & 302 & 39 & 588 \\
\hline$\%$ & 24.80 & 25.15 & 34.82 & 25.47 \\
\hline \multicolumn{5}{|c|}{ Other types of botulism } \\
\hline$N$ & 0 & 117 & 6 & 123 \\
\hline$\%$ & 0.00 & 9.74 & 5.36 & 5.33 \\
\hline \multicolumn{5}{|c|}{ Indeterminate type } \\
\hline$N$ & 0 & 0 & 24 & 24 \\
\hline$\%$ & 0.00 & 0.00 & 21.43 & 1.04 \\
\hline
\end{tabular}

${ }^{\text {a }}$ Suspected type C.

income in hryvnias and botulism CIR in Ukraine during 2002-2017, which was $-0.82 \pm 0.22(t=3.65)$ (a strong inverse statistical and expected relationship).

The structure of botulinum pathogen types is presented in Table 2. The distribution of types of botulism toxins is represented by type A $(7.97 \%)$, B (59.64\%), suspected as C $(0.56 \%)$, E (25.47\%), others $(5.33 \%)$, and unidentified (1.04\%). Human botulism caused by suspected type C toxin is rarely recorded in Ukraine, yet type C toxin seems responsible for 13 of 5229 cases. In addition, we assume that the cause of the decrease in type $\mathrm{B}$ and the increase in type $\mathrm{E}$ toxin are due to the more infrequent consumption of canned meat and increased consumption of fish products and their associated causes of botulism.

Table 3 presents the breakdown of food types as botulism transmission factors. During three observation periods (1955-1985, 1991-2002, and 2017-2018), the food products causing the disease were identified only in $85.27 \%$ of botulism cases. Canned meat products caused botulism in $49.47 \%$ of cases; canned fish products (dried and dehydrated fish) in
$32.25 \%$ of cases; canned mushrooms in $13.19 \%$ of cases; and canned vegetables in $5.09 \%$ of cases during three observation periods. From 1955-1985 to 2017-2018 periods, the proportion of meat products decreased from $48.02 \%$ to $33.86 \%$, the proportion of fish products increased from $31.22 \%$ to $58.27 \%$, canned mushrooms decreased from $16.33 \%$ to $3.54 \%$ and vegetable (plant) products-almost unchanged (4.44\% and $4.33 \%$ respectively). Food production trends changed, and so, the changed eating habits.

The way in which food products factored into botulism deaths is presented in Table 4 . The food products that caused the disease and death were identified only in $83.95 \%$ of fatal botulism cases. We observed a decrease in botulism CFR from all types of products. From 1955 to 2016, almost all cases of botulism in Ukraine were caused by homemade food products for consumption in individual households. There were isolated botulism cases associated with the consumption of industrially produced food products only in certain years during this period. In 2017-2018, cases of botulism caused by commercially manufactured food products increased to $32.56 \%$ of total 258 cases, including five deceased individuals. In 2017-2018, home canned foods were the cause of botulism for 162 patients $(62.79 \%)$ and for 12 patients $(16.67 \%)$ the origin of the food was not established.

Table 5 shows the CFR of various products that caused botulism in Ukraine. During the period 1955-2018, the largest CFR had fish products (15.99\%), and the smallest CFR (4.03\%) had meat products. The CFR of vegetable products was $7.93 \%$.

\section{Discussion}

In Ukraine during 1955-2018, there were 8614 cases, 6447 events, and 659 deaths of FB. Our results indicate a significant disparity in Ukraine in the distribution of FB over time. We believe that variations of botulism incidence depend on the cultural food habits of the population and the level of socioeconomic development, which can be gauged to some extent by macroeconomic indicators (HDI). A major risk factor for botulism is the prevalence of home-cooked canned foods. This practice depends on the economic well-being of the population and, to a lesser extent, on the desire for protein-rich food. Coming off of the Soviet famine in 19461947, Ukraine agricultural production grew by $8.00 \%$ per year through the late 1950s, although shortages of meat and fish persisted (Yekelchyk, 2007).

Food shortages after World War II, with minimal subsistence available to the population, and the overall low living standard resulted in very little household canning during this period. Significant growth in the living standard of the

Table 3. Food As a Factor of Botulism Transmission Among Botulism Infected in Ukraine in $1955-2018$

\begin{tabular}{lcccccr}
\hline & $\begin{array}{c}\text { No. of } \\
\text { cases } \\
\text { of botulism }\end{array}$ & $\begin{array}{c}\text { Food } \\
\text { product } \\
\text { known }\end{array}$ & $\begin{array}{c}\text { Percentage } \\
\text { of meat } \\
\text { products, \% }\end{array}$ & $\begin{array}{c}\text { Percentage } \\
\text { of fishery } \\
\text { products, \% }\end{array}$ & $\begin{array}{c}\text { Percentage } \\
\text { of mushroom } \\
\text { products, \% }\end{array}$ & $\begin{array}{c}\text { Percentage } \\
\text { of vegetable } \\
\text { products, \% }\end{array}$ \\
\hline $1955-1985$ & 1989 & 1464 & 48.02 & 31.22 & 16.33 & 4.44 \\
$1991-2002$ & 2982 & 2741 & 51.70 & 30.39 & 5.40 & 3.54 \\
$2017-2018$ & 258 & 254 & 33.86 & 58.27 & 13.19 & 5.33 \\
Total & 5229 & 4459 & 49.47 & 32.25 & 59 \\
\hline
\end{tabular}

We took cases with known food as $100 \%$. 
Table 4. Food As a Factor in the Transmission of Botulism Among the Dead FROM BOTULISM IN UKRAINE IN 1955-2018

\begin{tabular}{lcccccc}
\hline Years & $\begin{array}{c}\text { No. of } \\
\text { deaths } \\
\text { of botulism }\end{array}$ & $\begin{array}{c}\text { Food } \\
\text { product } \\
\text { known }\end{array}$ & $\begin{array}{c}\text { Percentage } \\
\text { of meat } \\
\text { products, \% }\end{array}$ & $\begin{array}{c}\text { Percentage } \\
\text { of fishery } \\
\text { products, \% }\end{array}$ & $\begin{array}{c}\text { Percentage } \\
\text { of mushroom } \\
\text { products, \% }\end{array}$ & $\begin{array}{c}\text { Percentage } \\
\text { of mushroom } \\
\text { products, \% }\end{array}$ \\
\hline $1955-1985$ & 231 & 174 & 17.82 & 57.47 & 19.54 & 5.17 \\
$1991-2002$ & 209 & 192 & 28.65 & 58.85 & 8.33 & 4.17 \\
$2017-2018$ & 21 & 21 & 14.29 & 80.95 & 0.00 & 4.76 \\
Total & 461 & 387 & 23.00 & 59.43 & 12.92 & 4.65 \\
\hline
\end{tabular}

We took cases with known food as $100 \%$.

Ukrainian population began in the late 1950s and continued until the Soviet Union collapse, although shortages of some foods (i.e., meat and fish) occurred until the mid-1990s. The increase in the living standard of the Ukrainian population during the 1960s-1980s led to the widespread preparation and consumption of home-cooked canned products without proper sterilization techniques. This situation contributed to the increasing incidence of botulism in Ukraine in the last decades before the Soviet Union collapse.

Examining global historical trends in botulism incidence, Eastern Europe had far more cases from 1958 to 1973 than all other regions (Jarvis and Patel, 1980). In the 1990s, the botulism incidence increased further in Ukraine and peaked in 1999 (345 cases). This increment was driven by the deep economic crisis following the collapse of the Soviet Union. Poverty and food shortages led to an even more widespread use of home canning as means of survival for a population during a prolonged economic crisis.

The reduction of CI, MR, and CFR botulism began in Ukraine in the early 2000s and continues till now. The downward trend in these indicators is explained by the overall improvement in Ukraine's macroeconomic indicators in recent decades. Other European countries showed a decrease of botulism in 2001-2013; the IR of botulism in Poland decreased from 0.17 to 0.06 per 100,000 population (Czerwiński et al., 2015). In Romania also was observed the botulism incidence decrease in the postcommunist period (Neghina and Neghina, 2011). We believe that the availability of affordable fresh food reduces domestic canning and botulism incidence.

A limitation of our study is the lack of data that directly indicate the prevalence of household food canning in the population. Thus, we have no direct evidence about the impact of the incidence of homemade canning practices on the botulism incidence in Ukraine. Nonetheless, we suggest

Table 5. Case Fatality Rate of Botulism Caused By DifFEREnt FoOdS IN UKRaIne IN 1955-2018

\begin{tabular}{lcccc}
\hline & $\begin{array}{c}\text { CFR of } \\
\text { meat } \\
\text { products, } \\
\%\end{array}$ & $\begin{array}{c}\text { CFR of } \\
\text { fishery } \\
\text { products, } \\
\%\end{array}$ & $\begin{array}{c}\text { CFR of } \\
\text { mushroom } \\
\text { products, } \\
\%\end{array}$ & $\begin{array}{c}\text { CFR of } \\
\text { vegetable } \\
\text { products, } \\
\%\end{array}$ \\
\hline Years & 4.41 & 21.88 & 14.23 & 5.14 \\
$1955-1985$ & 3.87 & 13.57 & 4.71 & 5.30 \\
$1991-2001$ & 3.49 & 11.49 & 0.00 & 9.09 \\
$2017-2018$ & 4.03 & 15.99 & 8.50 & 7.93 \\
Total & &
\end{tabular}

CFR, case fatality rate. that the rise in macroeconomic indicators demonstrates the availability of fresh produce to the population and contributes to the abandonment of home-canning practices.

Botulism incidence may depend on macroeconomic indicators that affect the eating habits of the population. The botulism incidence and MR grew during the economic crises. The distribution of various types of $C$. botulinum changed over the past 25 years (i.e., type B decrease and type $\mathrm{E}$ increase), which can be associated with increased canned fish products and decreased use of canned meat.

There was a general long-term trend toward a decrease in the incidence, mortality, and fatality from botulism during 1991-2018, which may have occurred due to improvements in the macroeconomic indicators (HDI) in Ukraine over the past 20-25 years. This correlation is indicated by the calculated average correlation coefficients of the inverse average force $(-0.75 \pm 0.20)$ between the defined macroeconomic indicators and botulism incidence in Ukraine.

However, in 2017-2018, the percentage of food produced for sale that caused botulism sharply increased to $32.56 \%$. This upward botulism trend can be interpreted as a negative consequence of the sanitary and epidemiological service termination in 2017 (Resolution No. 348, 2017), through which state monitoring and control over the production and sale of food products were lost. This demonstrates the decisive role of macroeconomic factors and the impact of inadequate public health monitoring/interventions on the botulism incidence in modern Ukraine.

\section{Conclusions}

FB is a life-threatening disease caused by the ingestion of food containing preformed BoNTs, which is the most potent natural poison known to humans. Based on the current challenges in the disease management and the potential use of botulinum toxins as biological weapons, FB is still considered a public health emergency (Scalfaro et al., 2019). Our study highlights key data and characteristics of FB epidemiology in Ukraine from 1955 to 2018. These data are being published for the first time in an English-language indexed journal and are an important contribution to the global picture of botulism.

Homemade canned meat and fish continue to be the leading causes of botulism in Ukraine. Cases related to commercial food were rare or absent, but in recent years (20172018), their incidence has increased to $32.56 \%$ due to the lack of proper government control over the production and sale of canned fish. FB in Ukraine is related to socioeconomic factors and traditional food habits of the population. Due to the declining living standards and uncertainty that food sources 
will be physically or economically available, homemade preservation increases, rendering the population at risk for botulism.

Ongoing botulism incidence testifies to the need for immediate effective action in nutrition, food safety, and health education fields, which could significantly reduce the burden of botulism in Ukraine. Clinicians should be aware of rare causes of infection, as botulism remains a diagnostic challenge, and misdiagnosis of early cases suggests sporadic cases are overlooked (Palma et al., 2019). Education and training activities should be focused both on authorities involved in disease management and on the general population to strengthen the surveillance system and decrease the life-threatening disease of FB.

\section{Acknowledgments}

The authors acknowledge the U.S. Department of Defense, Defense Threat Reduction Agency (DTRA), and the Biological Threat Reduction Program (BTRP) for facilitating the development of this article through the Science Writing Mentorship program in Ukraine and the financial support for publication of this article. DTRA/BTRP did not support the research described in this publication, and the contents are the responsibility of the authors and do not necessarily reflect the views of DTRA or the U.S. Government. The authors also thank the Public Health Center of the Ministry of Health of Ukraine for their support.

\section{Disclosure Statement}

No competing financial interests exist.

\section{Funding Information}

No funding was received for this article.

\section{References}

Anniballi F, Auricchio B, Fiore A, Lonati D, Locatelli CA, Lista F, Fillo S, Mandarino G, Medici D. Botulism in Italy, 1986 to 2015. Euro Surveill 2017;22:30550.

Arnon SS, Schechter R, Inglesby TV, et al. Botulinum toxin as a biological weapon: Medical and Public Health Management. JAMA 2001;285:1059-1070.

Barash JR, Arnon SS. A novel strain of Clostridium botulinum that produces type $\mathrm{B}$ and type $\mathrm{H}$ botulinum toxins. J Infect Dis 2014;209:183-191.

[CDC] Centers for Disease Control and Prevention. Botulism in the United States, 1899-1996. Handbook for Epidemiologists, Clinicians, and Laboratory Workers. Atlanta, GA: Centers for Disease Control and Prevention, 1998.

CDC, USA. 2018. Available at: https://emergency.cdc.gov/agent/ agentlist-category.asp accessed November 1, 2020.

Chatham-Stephens K, Fleck-Derderian S, Johnson SD, Sobel J, Rao AK, Meaney-Delman D. Clinical features of foodborne and wound botulism: A systematic review of the literature 1932-2015. Clin Infect Dis 2017;66(suppl_1):S11-S16.

Czerwiński M, Czarkowski MP, Kondej B. Foodborne botulism in Poland in 2013. Przegl Epidemiol 2015;69:243-245, 363365.

Fleck-Derderian S, Shankar M, Rao AK, et al. The epidemiology of foodborne botulism outbreaks: A systematic review. Clin Infect Dis 2017;66(suppl_1):S73-S81.
Jarvis B, Patel M. The occurrence and control of Clostridium botulinum in foods, Food and Health: Science and Technology. Eds GG Birch and KJ Parker. London: Applied Science Publishers Ltd., 1980, 101-114.

Maksymchuk MM. Flash botulism prevalence in Ukraine and preventive measures. Manuscript. Dissertation for a Candidate of Medical Sciences degree on the specialty 14.02.02Epidemiology. Bogomolets National Medical University, Kyiv, 2006.

Mann JM. Economic impact of a botulism outbreak. JAMA 1983;249:1299.

McLauchlin J, Grant KA, Little CL. Food-borne botulism in the United Kingdom. J Public Health 2006;28:337-342.

Neghina AM, Neghina R. Epidemiology of foodborne botulism in Romania 1980-2009. Foodborne Pathog Dis 2011;8:907911.

Palma NZ, Da Cruz M, Fagundes V, Pires L. Foodborne botulism, neglected diagnosis. Eur J Case Rep Intern Med 2019; 6:001122.

Peck MW, Smith TJ, Anniballi F, et al. Historical perspectives and guidelines for botulinum neurotoxin subtype nomenclature. Toxins (Basel) 2017;9:38.

Rasetti-Escargueil C, Lemichez E, Popoff MR. Public health risk associated with botulism as foodborne zoonoses. Toxins (Basel) 2019;12:17.

Resolution No. 348 of March 29, 2017, Kyiv. Cabinet of Ministers of Ukraine. Some issues of the State Sanitary and Epidemiological Service. Available at: https://zakon.rada.gov .ua/laws/show/348-2017-\%D0\%BF?lang=uk accessed November $1,2020$.

Scalfaro C, Auricchio B, De Medici D, Anniballi F. Foodborne botulism: An evolving public health challenge. Infect Dis 2019;51:97-101.

Tarkhashvili N, Chokheli M, Chubinidze M, Abazashvili N, Chakvetadze N, Imnadze P, Kretsinger K, Varma J, Sobel J. Regional variations in home canning practices and the risk of foodborne botulism in the Republic of Georgia, 2003. J Food Prot 2015;78:746-750.

Varma JK, Katsitadze G, Moiscrafishvili M, Zardiashvili T, Chikheli M, Tarkashvili N, Jhorjholiani E, Chubinidze M, Kukhalashvili T, Khmaladze I, Chakvetadze N, Imnadze P, Sobel J. Foodborne botulism in the Republic of Georgia. Emerg Infect Dis 2004;10:1601-1605.

Yekelchyk S. Ukraine: Birth of a Nation. New York, NY: Oxford University Press, 2007.

Zane Horowitz B. Type E botulism. Clin Toxicol (Phila) 2010; 48:880-895.

Zhang S, Masuyer G, Zhang J, Shen Y, Lundin D, Henriksson L, Miyashita S, Martínez-Carranza M, Dong M. Identification and characterization of a novel botulinum neurotoxin. Nat Commun 2017;8:14130.

Address correspondence to: Hennadii Mokhort, PhD Department of Epidemiology Bogomolets National Medical University 13 T. Shevchenko Boulevard Kyiv 01601 Ukraine

E-mail: h.mokhort@ukr.net 